7. Reprod. Fert. (1967) 13, 349-351

BRIEF COMMUNICATION

\title{
EFFECT OF FOETAL MASS ON GESTATION PERIOD IN MICE
}

\author{
ANNE MCLAREN \\ A.R.G. Unit of Animal Genetics, Edinburgh University
}

(Received 13th October 1966)

\begin{abstract}
Summary. A combination of mouse inbred strains was studied, in which foetal but not placental weight is greater in the $F_{1}$ hybrid than in the inbred litters. Gestation period was found to be shorter for the $F_{1}$ hybrid than for the inbred litters. It is concluded that, insofar as the length of gestation is inversely related to the mass of the conceptuses, it is the foetus rather than the placenta which matters.
\end{abstract}

For females of a given strain of mice, the length of gestation may be reduced by the following factors:

(a) Increased number of young in the litter, irrespective both of their distribution between uterine horns and of the number of corpora lutea (Biggers, Curnow, Finn \& McLaren, 1963).

(b) Mating with a male of a different inbred strain, so that the young are $\mathrm{F}_{1}$ hybrids (McLaren \& Michie, 1963; D. A. James, personal communication).

(c) Immunization of the female against tissue from a second inbred strain, followed by mating with a male of that strain; this produces an increase in both foetal and placental weight, and gives a further reduction in gestation period compared with (b) (James, 1965).

(d) Inclusion of at least one relatively advanced, transferred embryo in the litter (McLaren \& Michie, 1963).

In each case, the reduction in gestation period is associated with an increase in the total amount of both foetal and placental tissue in the litter. The observation by McCarthy (1965) that, in the JU ${ }^{\circ} \times \mathrm{R}$ III $\sigma^{*} \mathrm{cross}$, foetal size is increased over the inbred JU level but placental size is not, provides a good opportunity of testing which element of the conceptus is the more relevant to the shortening of gestation period-the foetus or the placenta.

Only first litters were studied. Nulliparous females of the JU strain were paired with JU or R III males, and examined daily for mating plugs. The day on which a plug was found was designated the first day of pregnancy. Pregnant females were either killed on the 18th day, and their foetuses and placentae counted and weighed, or they were examined for births twice a day from the 
18th day onwards, to determine the length of gestation. Some of the newborn litters were also weighed.

The results confirm McCarthy's (1965) finding, in that foetal weight was significantly higher in $F_{1}$ than in inbred pregnancies, but placental weight was not affected by the genotype of the litter (Table 1). At birth, the difference in

TABLE 1

WEIGHT OF FOETUSES AND PLACENTAE ON THE 18TH DAY OF GESTATION, AND YOUNG ON THE DAY OF BIRTH, IN LITTERS OF JU FEMALES MATED WITH JU MALES (INBRED LITTERS) OR $R$ III MALES ( $F_{1}$ HYBRID LITTERS)

\begin{tabular}{l|c|c|c}
\hline & Inbred & $F_{1}$ hybrid & $\begin{array}{c}\text { Significance } \\
\text { of difference }\end{array}$ \\
\hline No. of pregnancies & 17 & 15 & - \\
Mean foetal weight (mg) & $788 \pm 23$ & $860 \pm 16$ & $P<0.02$ \\
Mean placental weight (mg) & $119 \pm 4$ & $109 \pm 4$ & $P>0.2$ \\
Mean number in litter & $10 \cdot 2$ & 9.9 & - \\
\hline No. of pregnancies & 15 & 19 & - \\
Mean birth weight (mg) & $1420 \pm 32$ & $1500 \pm 31$ & $0.1>P>0.05$ \\
Mean number born & 8.3 & 8.4 & - \\
\hline
\end{tabular}

weight between inbred and $F_{1}$ young was about the same as it had been on the 18th day of gestation, but because of the greater variation among newborn young, the difference was not statistically significant (Table 1). Litter size was similar in the two groups.

Gestation was about half a day longer for females carrying inbred than for those carrying $F_{1}$ hybrid young (Table 2). Both groups showed a negative

TABLE 2

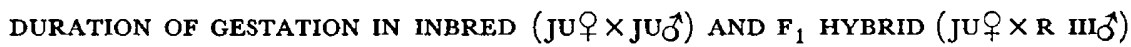
LITTERS

\begin{tabular}{l|c|c|c}
\hline & Inbred & $F_{1}$ hybrid & $\begin{array}{c}\text { Significance } \\
\text { of difference }\end{array}$ \\
\hline $\begin{array}{l}\text { No. of pregnancies } \\
\text { Mean gestation period (days) }\end{array}$ & 33 & 34 & - \\
Mean number born & $19 \cdot 71 \pm 0 \cdot 17$ & $19 \cdot 18 \pm 0.12$ & $P<0.02$ \\
& 8.9 & $8 \cdot 4$ & - \\
\hline
\end{tabular}

regression of gestation period on litter size, but the slope of the regression line was significantly steeper $(P<0.05)$ for the inbred than for the $F_{1}$ hybrid litters. The mean gestation period in the two groups was therefore compared, and found to differ significantly $(P<0.02)$. This procedure would tend to underestimate the difference in gestation length, since mean litter size was slightly larger in the inbred than in the $F_{1}$ hybrid group (Table 2).

Biggers et al. (1963) speculated that one way in which litter size might affect gestation length would be if oestrogens were produced by the placentae. The responsiveness of the uterus to oxytocin, and hence the time of onset of parturition, might depend on a threshold level of oestrogen acting on the uterus; if the 
oestrogens concerned were produced by the placentac, the time at which the threshold level was reached might depend upon the number of placentae present. If larger placentae produced more oestrogen, the effect of conceptus size on gestation length would also be explained. However, Harkness, McLaren \& Roy (1964) failed to detect any oestrogen in mouse placentae. The hypothesis becomes even less tenable in the light of the present evidence that an increase in foetal mass alone can reduce the length of gestation.

The shorter gestation length of $F_{1}$ hybrid litters might be interpreted as a direct immunological effect of the antigenic dissimilarity between the mother and the $F_{1}$ placentae, unrelated to the increased size of the $F_{1}$ young. If this were so, antigenic dissimilarity would be independently affecting both gestation length and foetal size (D. A. James, personal communication; one would also have to postulate a third independent effect, namely that of number in the litter on gestation length. It is simpler to suppose that gestation length decreases whenever foetal mass increases. The increase in mass could result either from the presence of a greater number of foetuses, or from an increase in their mean weight, whether this be brought about by the genetical or by the immunological consequences of hybridity.

\section{REFERENCES}

Biggers, J. D., Gurnow, R. N., Finn, G. A. \& McLaren, A. (1963) Regulation of the gestation period in mice. F. Reprod. Fert. 6, 125.

Harkness, R. A., McLaren, A. \& Roy, E. J. (1964) Oestrogens in mouse placentae. 7. Reprod. Fert. 8,411 .

JAMES, D. A. (1965) The effects of antigenic dissimilarity between mother and foetus on placental size in mice. Nature, Lond. 205, 613.

McCarthy, J. (1965) Genetic and environmental control of foetal and placental growth in the mouse. Anim. Prod. 7, 347.

Mclaren, A. \& Michie, D. (1963) Nature of the systemic effect of litter size on gestation period in nice. F. Reprod. Fert. 6, 139. 